\title{
Efficiency of Certain Arbuscular Mycorrhizal Fungi and Rhizosphere Bacterium Treatments on the Incidence of Corn Stem Borers Infestation
}

\author{
Mesbah, H.A. ${ }^{1}$, Aboul-Nasr, Amal ${ }^{2}$, EL-Sayed, Nagda Ahmed ${ }^{1}$ and Mohamed, Rokaia ${ }^{1}$
}

\begin{abstract}
Two field experiments were carried out at the experimental farm of Faculty of Agriculture (Saba-Basha), Alexandria University, at Abees region, Alexandria, Egypt, during two subsequent seasons of 2009 / 2010 and 2010 / 2011 to evaluate the treatment of arbuscular mycorrhizal fungi (AMF) and rhizosphere bacterium in addition to two current types of organic and mineral fertilizers on the lignin content in stems treated corn plants and the incidence of corn stem borers infestation.

The obtained results, showed lower mean values of inspected stem borers larvae accompanied by higher value of lignin content in the stems of inoculated corn plants with the endomycorrhizal fungus Glomus intraradices (G3) plus the rhizosphere bacterium Bacillus mycoides, in comparison to the uninoculated control in both current types of the adopted above mentioned fertilization.

The fact was ascertained by the deduced correlated values of determined lignin content in stem of corn plant for the detected levels of stem borers infestation however they showed a strong negative relationship values $(r=\mathbf{- 0 . 8 2}$ $\pm 0.12 \& r=-0.80 \pm 0.12)$ between them in case of both current normal tested types of the used fertilization. Though this detected negative relationship elucidates that when the lignin content in stem of corn plant increases, the infestation of stem borers decreases.
\end{abstract}

\section{INTRODUCTION}

Maize (Zea mays, L.) is the most important cereal crop, in Egypt, next to wheat. It is mainly used, by Egyptian farmer, for animal feed as well as human food consumption and in some industrial purpose for oil and starch extraction. Corn plants are usually attacked by three common injurious lepidopterous stem borers: the pink stem borer, Sesamia cretica Led., the purple lined borer, Chilo agamemnon Bles.- and the European corn borer Ostrinia nubilalis $\mathrm{Hb}$..

In recent years, many efforts have been made to avoid the damage caused by corn stem borers by using pesticides. However the extensive use of pesticides causes many hazardous side effects, i.e. resistance of insects to pesticides, reduction of natural enemies of insect pests and environmental pollution.

Therefore the determination of the most effective safe methods and practices for decreasing the level of infestation with stem borers on corn plants - of great value to be used in integrated control programme, in particular, bio-fertilizers, mineral fertilizers and foliar nutrients. Besides, they increase the plant tolerance to pest infestation and accompanied with high increase in yield (Mesbah et al., 2005 and 2007).

One of the most important biological control agents and bio-fertilizers are arbuscular-mycorrhizal fungi (AMF), which enhance nutrient uptake, plant growth and crop yield, particulary in case of phosphate and potassium deficiency in calcareous soils (EL-Awamy 2004).

Plant growth- promoting rhizobacteria (PGPR) are among the various groups of plant associated microorganisms that can elicit plant defenses. Bacillus spp. elicit induced systemic resistance (ISR) and also promote plant growth (Kloepper et al. 2004).

The objectives of this investigation are to study the positive effect of arbuscular-mycorrhizal fungus (AMF), Glomus intrardices, and rhizosphere bacterium, Bacillus mycoides, in comparison with certain foliar treatments on the incidence of corn stem borers, plant growth and yield.

\section{MATERIALS AND METHODS}

Two field experiments were carried out, using split plot design at the experimental farm of the Faculty of Agriculture, Saba Basha, Alexandria University, Alexandria, Egypt, during the growing seasons, 2009 and 2010. The treatments were done in three replicates, each consisted of five rows, two meters long with $25 \mathrm{~cm}$ distance between each hill, the total area of each replicate was $8.75 \mathrm{~m}^{2}(2.5 \times 3.5 \mathrm{~m})$. The experimental area was divided in two subsets. The first subset was supplied by the organic fertilizer (cattle manure) + NPK at the rate of $1: 1$; the second was treated only with NPK fertilizer.

Maize (Zea mays L.) variety Th.w. 310 was cultivated on April, the $11^{\text {th }}$ in the first growing season of 2009 and on April the $11^{\text {th }}$ and May the $11^{\text {th }}$ in the second growing season of 2010.Two mycorrizal strains of Glomus intrardices were used in these experiments. The first (G.3) was isolated at the Experimental Station of Alexandria University, at Abees, (Aboul Nasr, 1993a), was used in both seasons. The second (G.4) was

\footnotetext{
${ }^{1}$ Plant Protection, Dept., Fac. Agric., Saba-Basha, Alex., Univ.

${ }^{2}$ Agric. Botany Dept., Agricultural Microbiology, Fac. Agric.,

Saba-Basha, Alex., Univ.

Received November 9, 2012, Accepted December 13, 2012
} 
supplied by "Amykor company", Germany. The inoculum consisted of expanded clay aggregates (2.4 $\mathrm{mm}$ in diameter, Leca), contains chlamydospores and fungus mycelium, which had been produced on Tagetes erecta. L. (Aboul Nasr, 2004). The inoculum was applied before sowing at the rate of $7 \mathrm{~g} /$ hill. The control plants received the same amount of heat sterilized expanded clay. Bacillus mycoides was obtained from the German Collection of Microorganisms and Cell Cultures, Germany. The bacterial inoculum was adjusted at the concentration $1.6 \times 10^{6}$ bacterial cell $/ 1 \mathrm{ml}$ sterilized water by using a hemocytometer slide. Maize grains were dipped in the bacterial suspension for two hours before sowing. After planting, each hill received $10 \mathrm{ml}$ from the above mentioned bacterial suspension in the case of bacterial treatment. The performed treatments of evaluated mycorrhizal strains of $G$. intraradices, the Rhizosphere bacterium B. mycoides, the bio-fertilizers of Nitropin \& Phosphorin and the foliar insecticide - Runner ${ }^{(\mathrm{R})}$, Moulting Accelerating Compounds (MAC), are included in Table, (1). Moreover, each of the tested foliar (MAC), fertilizers and their applied rates are presented in Table, (2).

1- The percentage of mycorrhizal root length colonization

The percentage of mycorrhizal root length colonization was estimated three times after sowing, when plants were 70 day old and at harvest (110 day old) by the examination of cleared and stained $1 \mathrm{~cm}$ root segments using a research microscope for each treatment.

The procedure was done according to Gianinazzi (2004).

The percentage of AM root colonization was estimated according to the following equation (Giovannetti and Mosse, 1980).
AMF root colonization $(\%)=$

Number of segements containing AM

Total number of examined segements $\times 100$

\section{2 - Determination of lignin compound:}

Total lignin compound was determined using the method described by Ride (1975) when plants were 70 day old.

3- Sampling technique of the corn stem borers:

At the end of the season (post harvest time), random samples, each of the ten corn stalks, were collected from each treatment and examined; the infested stalks with inspected borers species were identified, counted and recorded.

\section{RESULTS and DISCUSSION \\ 1 - The percentage of root length colonization}

Glomus intraradices isolate G3 was used during the growing season, 2009. Whereas, isolates G3 and G4 were used in $(2010$ / 2011) seasons. The percentage of AM colonization was examined when plants were 70 days old and at the end of experiment (110 day). Figures $1,2,3,4,5,6$ show that the percentage of mycorrhizal root length colonization in inoculated corn plants with $G$. intraradices (G3) was significantly increased either in case of organic or mineral fertilizer compared to uninoculated ones.

On the other hand, significant difference were observed in the presence of dual inoculation with $G$. intraradices and Bacillus mycoides compared to inoculated plants with G. intraradices (G3) alone. The highest percentage of AM root length colonization was noticed at the end of the experiment (at harvest) in the presence of organic fertilizer. The same trend was observed during 2010 / 2011 either for the early or lately growing seasons (Figs. 3, 4, 5, 6).

Gryndler et al. (1990) showed the balanced fertilizer stimulated mycorrhizal colonization of corn while fertilization with unusually high or low levels of $\mathrm{N}$ decreased colonization.

Table1. The applied treatments on corn plants during the two growing seasons of 2009 and 2010

\begin{tabular}{cc}
\hline Treatments in 2009 & Treatments in 2010 \\
\hline Untreated control & Untreated control $^{(\mathrm{R})}(\mathrm{MAC})$ \\
Runner $^{(\mathrm{R})}(\mathrm{MAC})$ & Runner $^{(\mathrm{R})}$ \\
Nitropin+Phosphorin & Nitropin+Phosphorin \\
Bacillus mycoides & Bacillus mycoides \\
Glomus intraradices $(\mathrm{G} 3)$ & Glomus intraradices $(\mathrm{G} 3)$ \\
G3 + B. mycoides & G3 + B. mycoides \\
& G. intraradices $(\mathrm{G} 4)$ \\
& G4 + B. mycoides \\
\hline
\end{tabular}


Table 2. The tested foliar material, fertilizers types and their application rates

\begin{tabular}{lll}
\hline Material & Structure \\
1-Insecticides Methoxyfenozide \\
(Runner ${ }^{\circledR} \mathrm{SC}$ 24\%) an insect \\
moulting accelerating hormone \\
(MAC) \\
(3-methoxy-o-toluoyl)-3,5-xylohydrazide
\end{tabular}

\section{2-Bio-fertilizers}

\begin{tabular}{|c|c|c|c|}
\hline A. Nitropin ${ }^{\circledR}$ & \multirow{2}{*}{$\begin{array}{l}\text { Produced by the Egyptian Ministry of } \\
\text { Agriculture }\end{array}$} & $1000 \mathrm{~g} / \mathrm{fed}$ & \multirow[t]{2}{*}{ ST } \\
\hline B. Phosphorin ${ }^{\circledR}$ & & $600 \mathrm{~g} / \mathrm{fed}$. & \\
\hline \multicolumn{4}{|l|}{3 Mineral fertilizers } \\
\hline $\begin{array}{l}\text { A. Nitrogen fertilizer } \\
\text { Ammonium nitrate }\end{array}$ & $\mathrm{NH}_{4} \mathrm{No}_{3}(33.5 \% \mathrm{~N})$ & $\begin{array}{l}175 \mathrm{Kg} \\
175 \mathrm{~kg}\end{array}$ & $\begin{array}{l}21 \text { DAS } \\
\text { 36 DAS }\end{array}$ \\
\hline $\begin{array}{l}\text { B. Phosphorous fertilizers } \\
\text { Mono Calcium Phosphate }\end{array}$ & Containing $15.5 \% \mathrm{P}_{2} \mathrm{O}_{5}$ & $100 \mathrm{~kg}$ & SP \\
\hline $\begin{array}{l}\text { C. Potassium fertilizer } \\
\text { Potassium Sulfate }\end{array}$ & $\mathrm{K}_{2} \mathrm{So}_{4}$ containing $48 \% \mathrm{~K}_{2} \mathrm{O}$ & $25 \mathrm{~kg}$ & $21 \mathrm{DAS}$ \\
\hline 4 - Organic fertilizer & $\begin{array}{l}\text { Cattle manure }(\mathrm{pH}=7.2, \mathrm{OM} \%=35.5, \mathrm{OC} \%= \\
22.6, \\
\text { Total } \mathrm{N} \%=2.05 \text {, Total } \mathrm{P} \% 1.20 \text {, Total } \mathrm{K} \%= \\
1.50 \text { and } \mathrm{C} / \mathrm{N} \text { ratio is } 11.5: 1)\end{array}$ & $10-20 \mathrm{~m}^{3}$ & SP \\
\hline
\end{tabular}

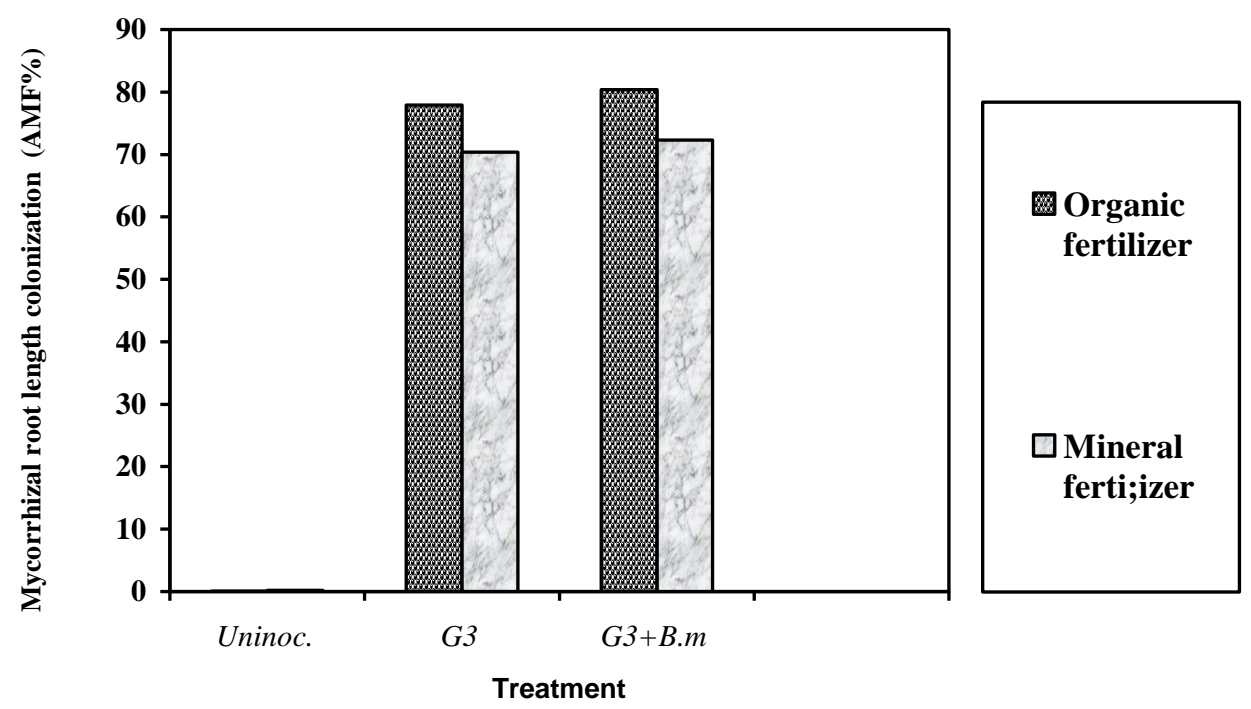

Figure1. Effect of inoculated corn plants with Glomus intraradices (G3) and Bacillus mycoides on the percentage of root length colonization at 70 days during the early growing season 2009/2010 


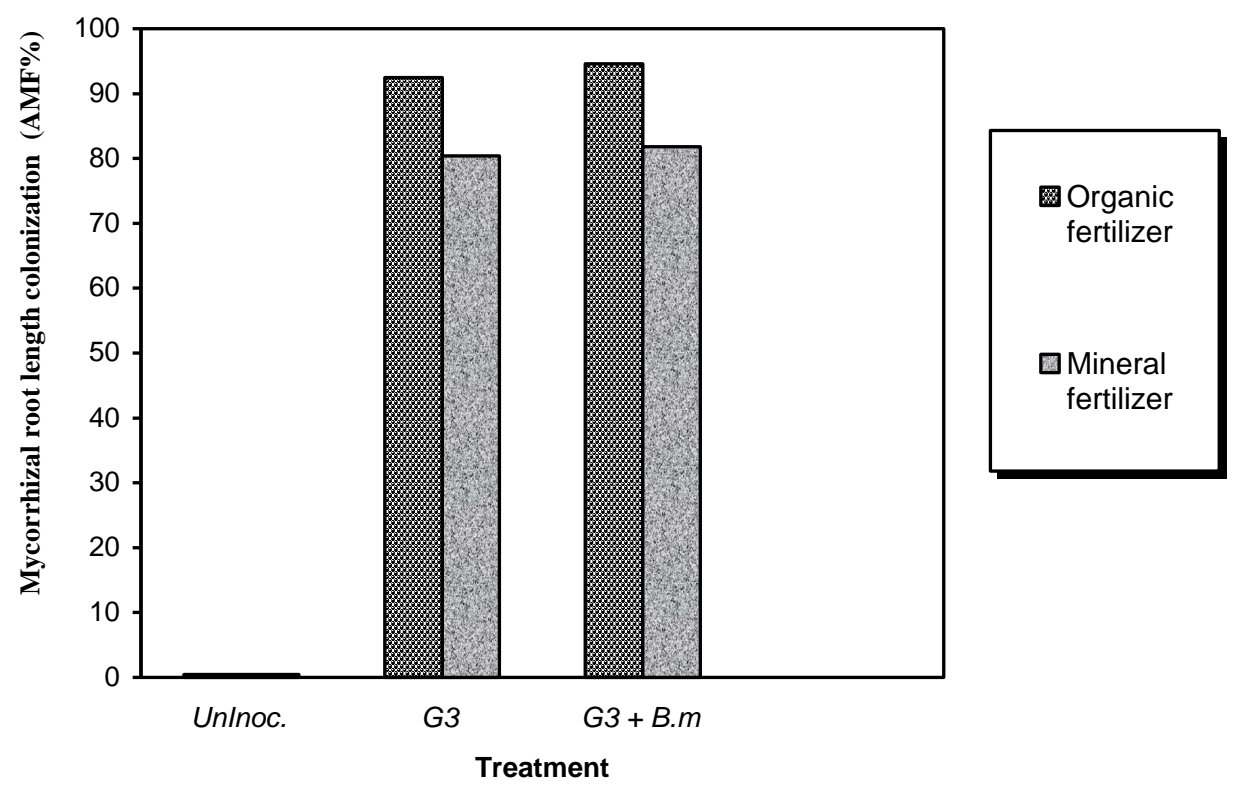

Figure 2. Effect of inoculated corn plants with $G$. intraradices (G3) and B. mycoides on the percentage of root length colonization at the end of experiment (110 days) during the early growing season 2009/2010

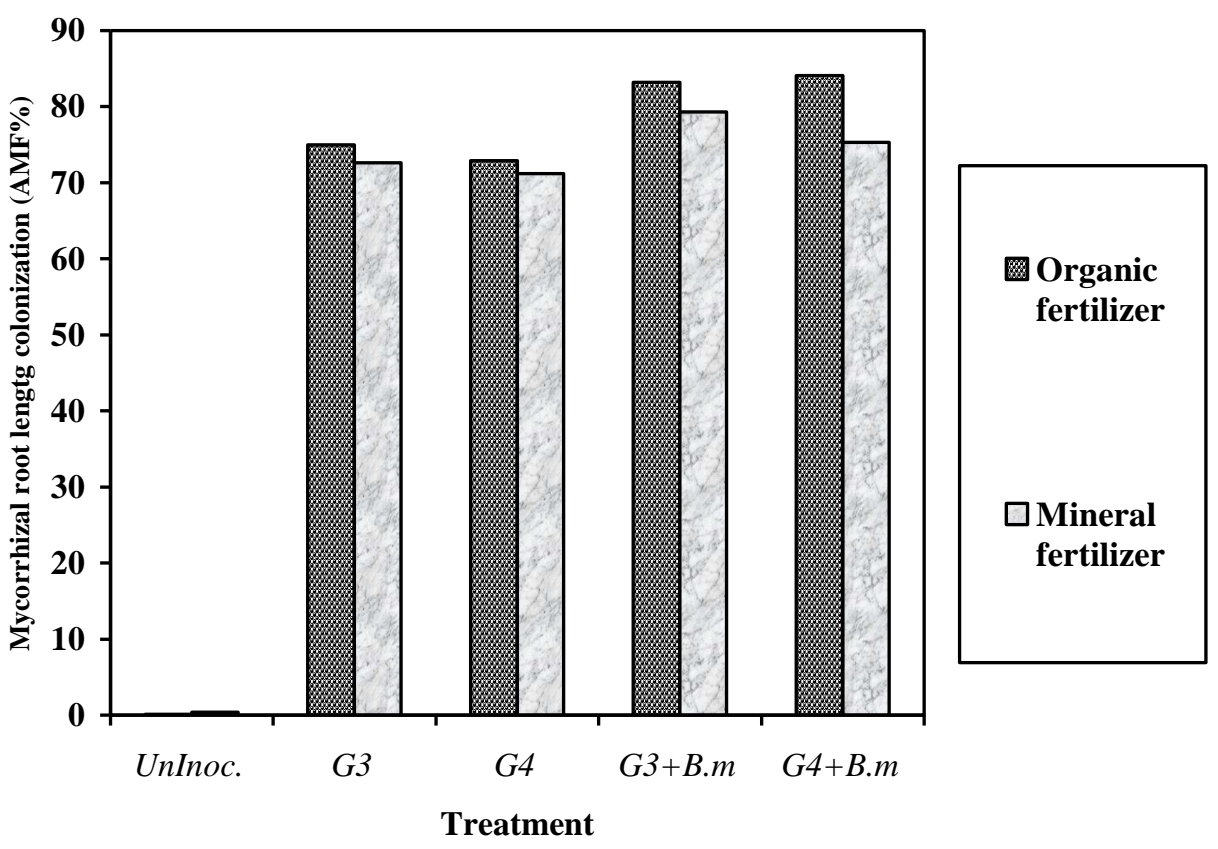

Figure 3. Effect of inoculated corn plants with G. intraradices (G3\&G4) and B. mycoides on the percentage of root length colonization at 70 days during the early growing season 2010/2011 


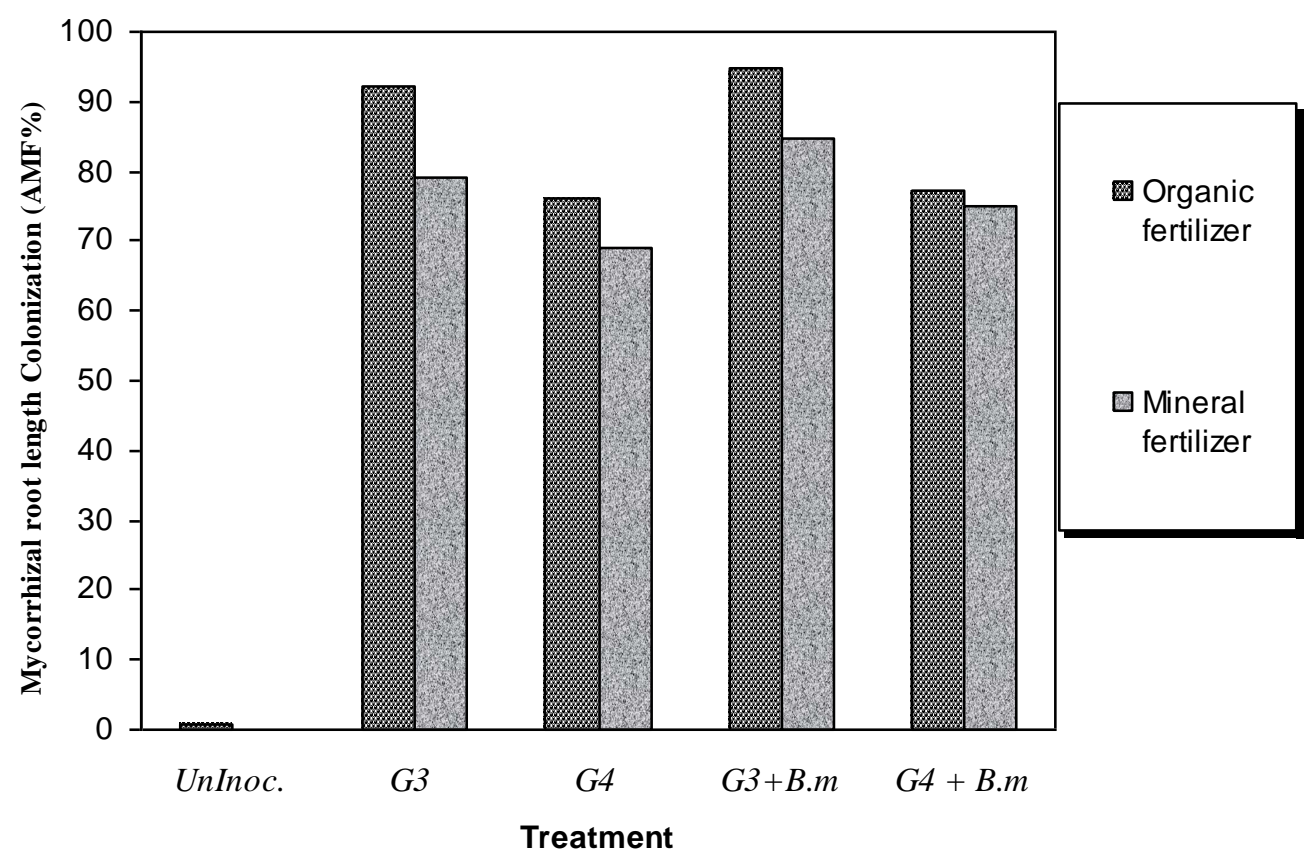

Figure 4. Effect of inoculated corn plants with G. intraradices (G3\&G4) and B. mycoides on the percentage of root length colonization at the end of experiment (110 days) during the early growing season $2010 / 2011$

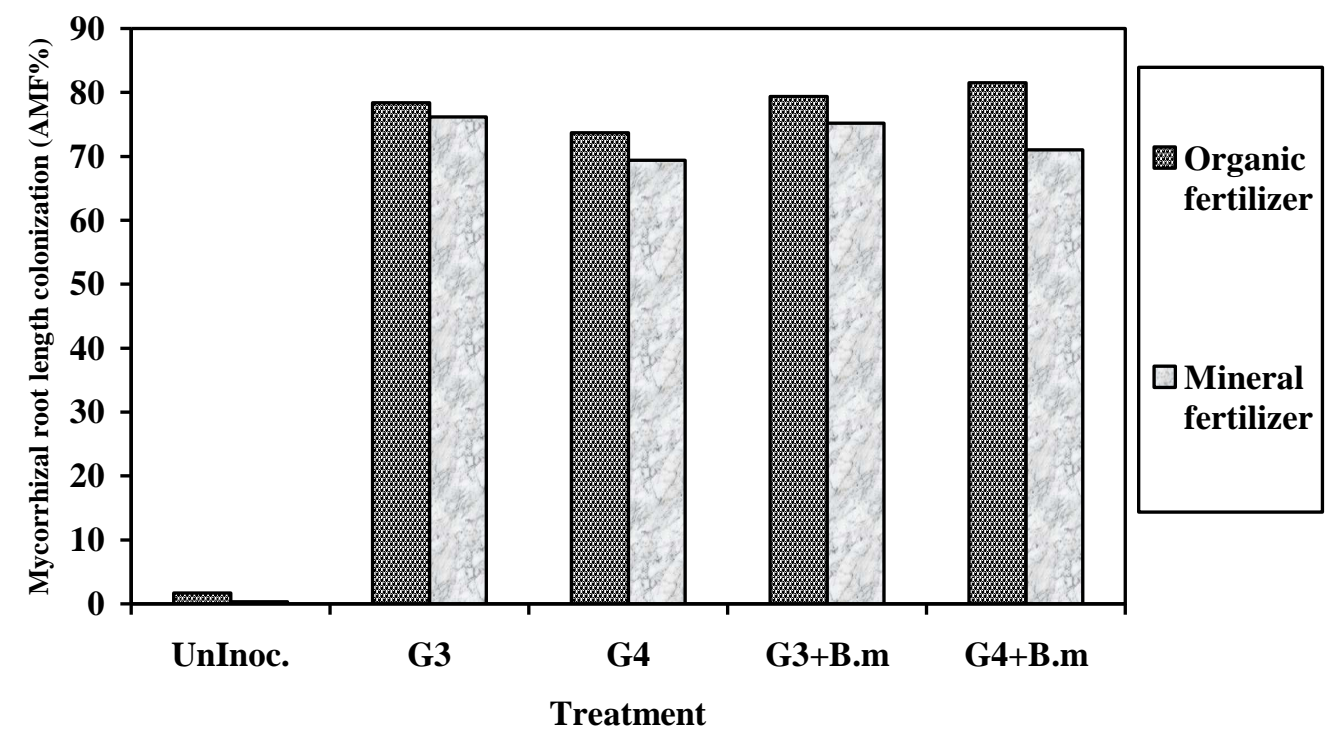

Figure 5. Effect of inoculated corn plants with G. intraradices (G3\&G4)) and B. mycoides on the percentage of root length colonization at 70 days during the lately growing season 2010/2011 


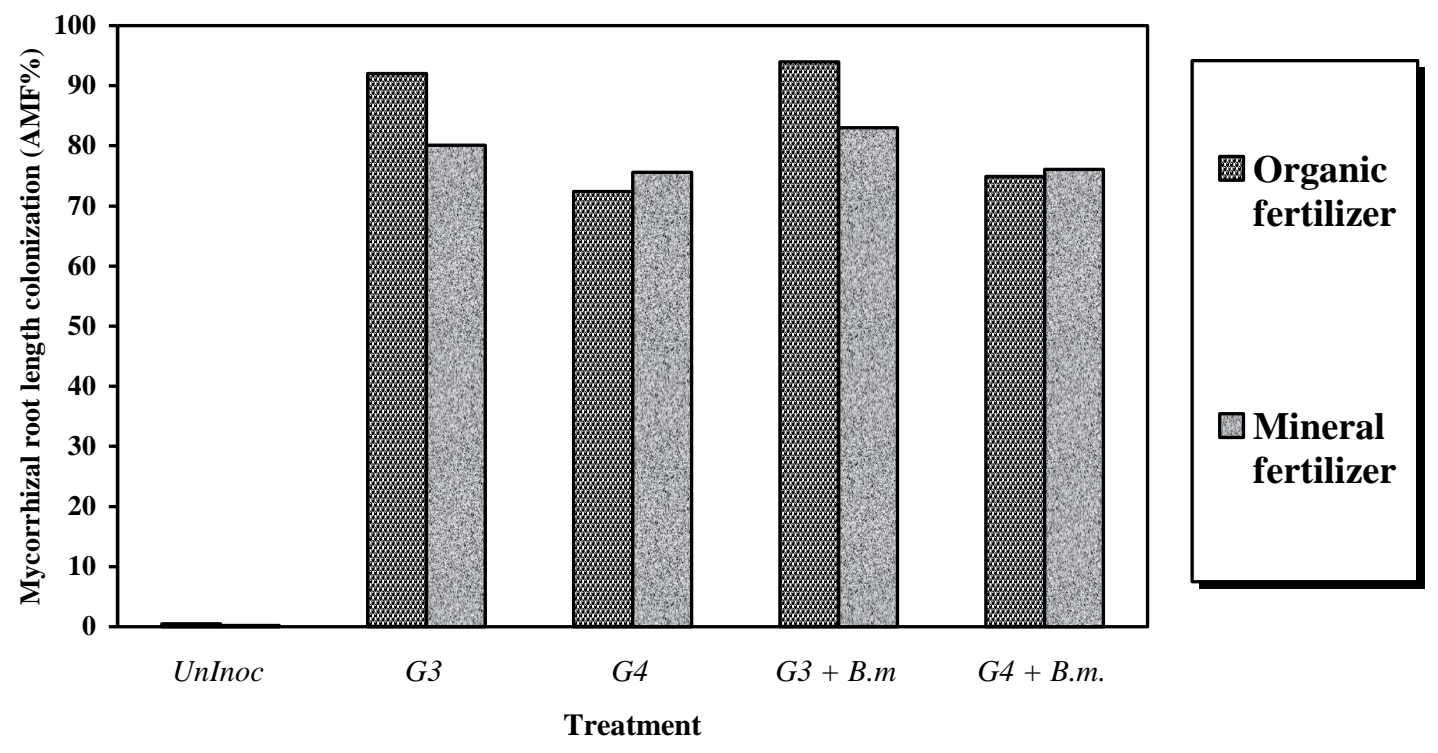

\section{Figure 6. Effect of inoculated corn plants with G. intraradices (G3\&G4) and B. mycoides on the percentage of root length colonization at the end of experiment (110 days) during the \\ lately growing season $2010 / 2011$}

Aboul-Nasr (1996) studied the effect of the rhizobacterium, Bacillus mycoides, on the development of mycorrhizal root length colonization in flax plants (Linum usitatissimum). B. mycoides significantly increased the mycorrhizal root length colonization for both Glomus intraradices and G. etunicatum. The presence of mycorrhizal fungi enhanced the root exudation which influence the population of rhizobacterium and Glomus intraradices was able to stimulate the introduction of beneficial bacteria in rhizosphere soil

Aboul-Nasr and EL-Fayoumy (2003) found that the arbuscular mycorrhizal fungi (AMF) isolate Glomus etunicatum was eximaned in a combination with different levels of phosphorous fertilizer on the growth and yield of maize (Zea mays L.) plants under field conditions. Inoculated plants with low and medium levels of $\mathrm{P}_{2} \mathrm{O}_{5}$ had led to increase the percentage of infected roots significantly $(61.67-65.0 \%)$ compared to uninoculated plants.

2 -The integrated effect of different evaluated bio-

fertilizers and the used fertilization types on the incidence of stem borers infestation during the early growing season of 2009:-

Results in Table (3) show the revealed effects of each of tested bio-fertilizers alone and / or in combination with each of the evaluated organic and / or mineral fertilization type on the incidence of infestation with stem borers species at early growing season of 2009. In this respect, both of the adopted organic and mineral fertilization types to a more or a less extent, decreased the rate of inspected stem borers infestation 2.6 - $12.16 \& 3.06-11.33$ / 30 plants in comparison to the untreated control $12.53 \& 15.5 / 30$ plant, respectively. Indicating the obviously detected positive effect of organic type during the early growing summer season 2009. Herein, the higher estimated mean number of infested plants were $12.16 \& 11.33$ / 30 plants in case of the tested (MAC) Runner ${ }^{(R)}$ under the conditions of both of the organic and the mineral types, respectively. While, the revealed beneficial bio-performance of tested Glomus intraradices (G3) and/or (G3 + B. mycoides was represented by a rather decreased rate of the infested corn plants, which was more pronounced for the organically fertilized corn plants than the mineraly fertilized ones ( $2.6 \& 2.66 / 30$ plants) and $(3.53 \& 3.06$ / 30 plants) (Table 3 ).

3 - Effect of sowing date and different evaluated biofertilizers and the used fertilization types on the incidence of stem borers infestation during the growing season 2010 of corn plants:-

A- The early growing season of 2010:-

The initiated experiments throughout the growing season of early sown corn plants, on April $11^{\text {th }}, 2010$, proved the beneficial effect of all evaluated biofertilizers in reducing the infestation levels of corn stem borers species, in comparison to the untreated control and / or the performed treatment of the tested (MAC) Runner ${ }^{(\mathrm{R})}$ (Table 4). 
Table 3. The integral effect of the adopted treatments with both tested current fertilization types on the incidence of stem borers infestation in the early sowing date, April, $11^{\text {th }}, 2009$

\begin{tabular}{|c|c|c|c|c|}
\hline \multirow{3}{*}{ Treatments } & \multicolumn{4}{|c|}{ Fertilization types } \\
\hline & \multicolumn{2}{|c|}{ Organic } & \multicolumn{2}{|c|}{ Mineral } \\
\hline & Mean * & $\pm \% * * *$ & Mean* & $\pm \% * * *$ \\
\hline Untreated control & $12.53^{\mathrm{a}} * *$ & & $15.50^{\mathrm{a}} *$ & \\
\hline Runner $^{(\mathrm{R})}$ (MAC) & $12.16^{\mathrm{a}}$ & -2.95 & $11.33^{\mathrm{b}}$ & -26.90 \\
\hline Nitropin+Phosphorin & $7.93^{b}$ & -36.95 & $7.83^{\mathrm{c}}$ & -49.48 \\
\hline Bacillus mycoides & $7^{b}$ & -44.13 & $7.65^{c}$ & -50.64 \\
\hline Glomus intraradices $(\mathrm{G} 3)$ & $2.60^{\mathrm{c}}$ & -79.24 & $3.53^{d}$ & -77.22 \\
\hline $\mathrm{G} 3+B$. mycoides & $2.66^{c}$ & -78.77 & $3.06^{\mathrm{d}}$ & -80.25 \\
\hline LSD $_{50}$ & \multicolumn{2}{|c|}{1.451} & \multicolumn{2}{|c|}{1.356} \\
\hline
\end{tabular}

* Mean / 30 plants / treatment

** Means followed by the same letter (s) are not significantly different

$* * * \pm \%$ Increase or decrease compared with uninoculated plants

Table 4. The combined effect of tested treatments with both tested current fertilization types on the incidence of stem borers infestation in the early sowing date, April, $11^{\text {th }}, 2010$

\begin{tabular}{|c|c|c|c|c|}
\hline \multirow{3}{*}{ Treatments } & \multicolumn{4}{|c|}{ Fertilization types } \\
\hline & \multicolumn{2}{|c|}{ Organic } & \multicolumn{2}{|c|}{ Mineral } \\
\hline & Mean * & $\pm \% * * *$ & Mean * & $\pm \% * * *$ \\
\hline Untreated control & $12.36^{\mathrm{a}} * *$ & & $15.20^{\mathrm{a}}$ & \\
\hline Runner $^{(\mathrm{R})}$ (MAC) & $11.46^{\mathrm{a}}$ & -7.28 & $11.7^{\mathrm{b}}$ & -23.02 \\
\hline Nitropin+Phosphorin & $7.03^{b}$ & -43.12 & $7.8^{c}$ & -48.68 \\
\hline Bacillus mycoides & $6.46^{b}$ & -47.73 & $7.56^{\mathrm{c}}$ & -50.26 \\
\hline Glomus intraradices (G3) & $3.16^{\mathrm{c}}$ & -74.43 & $3.80^{\mathrm{d}}$ & -75 \\
\hline G. intraradices $(\mathrm{G} 4)$ & $3.66^{\mathrm{c}}$ & -70.38 & $3.70^{d}$ & -75.65 \\
\hline $\mathrm{G} 3+$ B. mycoides & $2.7^{\mathrm{c}}$ & -78.15 & $3.10^{\mathrm{d}}$ & 79.60 \\
\hline $\mathrm{G} 4+B$. mycoides & $3.13^{c}$ & -74.67 & $3.88^{\mathrm{d}}$ & -74.80 \\
\hline LSD $_{50}$ & & & & \\
\hline
\end{tabular}

* Mean / 30 plants / treatment

** Means followed by the same letter (s) are not significantly different

$* * * \pm \%$ Increase or decrease compared with uninoculated plant

These results ascertained the obvious increase of detected positive bio-performance of organic fertilization type on the measured reduction of infestation during the early growing summer season of 2010. In this concept, the higher estimated mean number of infested plants amounted to $11.46 \& 11.7$ / 30 plants in case of the tested (MAC)- Runner ${ }^{(\mathrm{R})}$ under the condition of both of the organic and the mineral fertilization types, respectively. While, the high beneficial effect of Glomus intraradices (G3) and Glomus intraradices (G4) plus Bacillus mycoides treatments was confirmed by the decreased infestation rate up to a range between $3.16 \& 3.13$ / 30 plants in case of the organically fertilized plants and $3.8 \& 3.83$ / 30 plants in the mineraly fertilized ones (Table 4 ).

$B$ - The lately growing season 2010

The exhibited results in Table 5 show the detected effects of each of the evaluated bio-fertilizers and the (MAC)-Runner ${ }^{(\mathrm{R})}$ on the incidence of stem borers

infestation. The important role of sowing date on the incidence of stem borers infestation was clearly ascertained by the comparatively varied levels of determined borers infestation in the early cultivated corn plants on April, 11 ${ }^{\text {th }}, 2010$, which was somewhat, more or less, lowered than or increased that estimated values for the lately sown plants on May, $11^{\text {th }}$, and ranged in all the conducted treatments from 2.43 to 13.20 and from 3.20 to 13.46 / 30 plants regardly (Table 5).

Identically, the efficiency of different tested biofertilizers on various species of economic pests are mentioned in the work of many investigators, i.e. Mesbah et al. (2002a) who explained the profitable effective sustainable strategy for the controlling injurious insect pests of corn plants. In this concern, they investigated the sowing date, planting space, foliar fertilizers (macro and micro nutrients) and mineral or bio-fertilization to evaluate their role as tools in the socalled Integrated Pest Management (IPM) program of 
corn pests. It was concluded that planting spaces of 60 and $70 \mathrm{~cm}$ apart between furrows insignificantly affected the level of stem borers infestation; the biofertilized corn plants were more tolerant to the infestation by the stem borers than the mineraly fertilized ones; the dressing of corn grains with the biofertilizers-Phosphorin \& Rhizobacterin before sowing to some extent lowered the levels of infestation by Chilo agamemnon and Ostrinia nubilalis.The use of foliar nutrients \& fertilizer types in both sowing dates gave positive interaction effects in decreasing levels of stem borers infestation and greatly improved the yield and its characteristics of corn plants; and all of such followed agricultural practices enabled corn plants to tackle the going on infestation; thus crop loss due to the attack of stem borers could be compensated.

Moreover, Mesbah et al. (2002b) performed field practices on the early sown (May $1^{\text {st }}$ ) or lately sown (June $2^{\text {nd }}$ ) corn plants with Phosphorin \& Rhizobacterin as bio-fertilizers and sprays of six selected foliar nutrients in mono-, bi- and / or tri-sequence applications to determine their beneficial effects in checking the incidence of the stem borers and hence increasing the corn yield. Results assured the profitable effects of using foliar nutrients as well as the bio-fertilizers for attaining healthy corn plants, which would be capable of tolerating the injury inflicted by the stem borers and compensating for the harmful effects of insect infestation. So high grain yields could be obtained than those of the untreated and / or the insecticides treated plants. Hol and Cook, (2005) found that the interest in AMF-nematode interactions lies in the possibility of enhanced resistance or tolerance of AMF-infected plants to nematodes, and the potential value of this for the control of crop pests.
4- The Effect of different tested bio-fertilizers \& fertilization types on the determined lignin content in the stems of inspected maize plants during the lately growing season of $\mathbf{2 0 1 0}$

Results in Table (6) elucidate the revealed effects of each tested bio-fertilizer on the determined lignin content in stems of maize plants under the conditions of each evaluated organic and / or mineral fertilization types.

In this respect, each of performed bio-fertilizer treatment in presence of the adopted organic fertilization type, to a more or a less extent, increased the measured lignin content in maize stem from 1.34 to 1.96 in comparison to the minerals fertilized plants (1.09 - 1.65) and the untreated control (1.01\& 1.21) (Table 6).

A high beneficial bio-performance of Glomus intraradices (G3) and Glomus intraradices (G4)+ Bacillus mycoides treatments was proved by the estimated increased value of lignin content up to 1.75 and 1.62 in the organically fertilized plants and 1.49 and 1.53 in the minerally fertilized ones compared to the untreated plants. While, the utmost efficient bioperformance was recorded for the treated plants with Glomus intraradices (G3) + Bacillus mycoides in case of both used fertilization types, indicating an increased value of lignin content in the stem of corn plants reached 1.96 and 1.65 , in comparison to the other performed treatments and the untreated control (Table, 6).

In addition, the calculated values of determined lignin content in inspected stems of maize plants correlated with the detected levels of stem borers infestation Table (7). Herein, the results in Table (7) show the negative strong relationship between the lignin content in stems of maize plants and the measured levels of occurred stem borers infestation in the presence of both types of used normal fertilization.

Table 5. The integrated effect of performed treatments and the used normal current fertilization types on the incidence of stem borers infestation in lately sowing date, May, $11^{\text {th }}$, 2010

\begin{tabular}{|c|c|c|c|c|}
\hline \multirow{3}{*}{ Treatments } & \multicolumn{4}{|c|}{ Fertilization types } \\
\hline & \multicolumn{2}{|c|}{ Organic } & \multicolumn{2}{|c|}{ Mineral } \\
\hline & Mean * & $\pm \% * * *$ & Mean * & $\pm \% * * *$ \\
\hline Untreated control & $16.6^{\mathrm{a} * *}$ & & $17.20^{\mathrm{a}} * *$ & \\
\hline Runner $^{(R)}$ (MAC) & $13.2^{b}$ & -20.48 & $13.46^{b}$ & -21.74 \\
\hline Nitropin+Phosphorin & $7.66^{\mathrm{c}}$ & -53.85 & $13.26^{\mathrm{b}}$ & -22.90 \\
\hline Bacillus mycoides & $6.20^{d}$ & -62.65 & $7.7^{\mathrm{c}}$ & -55.23 \\
\hline Glomus intraradices (G3) & $2.83^{\mathrm{e}}$ & -82.95 & $3.66^{\mathrm{d}}$ & -78.72 \\
\hline G. intraradices (G4) & $3.73^{\mathrm{e}}$ & -77.53 & $3.23^{\mathrm{d}}$ & -81.22 \\
\hline $\mathrm{G} 3+$ B. mycoides & $2.43^{\mathrm{c}}$ & -85.36 & $3.20^{\mathrm{d}}$ & -81.39 \\
\hline $\mathrm{G} 4+$ B. mycoides & $3.7^{\mathrm{e}}$ & -77.71 & $3.23^{\mathrm{d}}$ & -81.22 \\
\hline LSD $_{50}$ & & & & \\
\hline
\end{tabular}


Gibson et al. (2009) determined that corn stalk has an effect on southwestern corn borer (Diatraea grandiosella Dyar) survival during different growth stages. It was believed that as the stalks accumulated more lignins and fibers, the stalk would become harder and causing decrease of survival of corn borers. Bi et al. (2010) found that the major component of cell wall, is lignin which plays an important role in plant development and defense response to pathogens. BarrosRios J et al. (2011) found that European and Mediterranean corn borers are two of the most economically important insect pests of maize. Besides, the thickness of cell wall could be the initial barrier against corn borer larvae attack.

Many plant pathogens and insect can be controlled only with expensive physical or chemical treatments. Mycorrhizae offer an alternative approach on what we should pursue their potential as biological control agents despite the obstacles.

A combined application of both AMF and Bacillus mycoides in the field becomes feasible. The first will improve plant health in general and resistance against soil - borne pathogens, nematodes and corn stem borers in particular. The second could be enhancing the potential for successful mycorrhizal formation, stimulatory bacteria could be selected and co-inoculated with mycorrhizal fungi.

\section{REFERENCES}

Abou-Nasr, A. (1993a). Identification of VA-mycorrhizal fungi in soil of Alexandria Governorate. Alex. J. Agric. Res., 38(2): 371-376.

Aboul-Nasr, A. (1996). Stimulation of vesicular-arbuscular mycorrhizal by Bacillus mycoides on flax. Alex. J. Agric. Res., 41(1): 261-270.

Aboul-Nasr, A. (2004). Method of producing an inoculum of endomycorrhizal fungi. Academy Sci. Res. and Tech. Egypt. Patent No. 23234

Abou-Nasr, A., A.Y., EL-Sharkawy and M.G. Hassouna (1993b). Effect of endomycorrhiza and N-fixing rhizobacteria on plant growth and development of fusarium root rot of cucumber in calcareous soil. J. Agric. Sci., Mansoura Univ., 18(6): 1739-1744.

Aboul-Nasr, A. and M.E EL-Fayoumy (2003). Evaluation of AM mycorrhizal inoculums on the yield of maize plants under mycorrhizae. ICOM4, August 10-15, Montrial, Canada. p205 (Abs).

Barros-Rios, J., R.A. Malvar, H.J.G. Jung and R. Santiago. (2011). Cell wall composition as a maize defense against corn borers. Phytochemistry, 72:365-371.

Bi, C., F. Chen, L. Jackson, B. S. Gill and W. Li (2011). Expression of lignin bio-synthetic genes wheat during development and upon infection by fungal pathogens. Plant Mol. Biology, 29: 149-161.
EL-Awamy, A. A. M. A. (2004). Effect of nitrogen, phosphorous and sulfur levels in soil on bradyrhizobium and mycorrhiza interaction in cowpea plants under calcareous soil condition. Ph.D., Fac. Agric. (Saba Basha), Alex. Univ., 163 p.

Gianinazzi, S. (2004). Genomyca workshop on" Technological transferin arbuscular mycorrhiza research". March 1-4, in INRA at Dijion, France.

Gibson, B.K., C.D. Parker and F.R. Mursser (2009). Corn stalk penetration resistance as a predictor of southwestern corn borer (Lepidoptera: Crambidae) survival. Dep. of Entomology and Plant pathology Mississippi State University, 3: 7-17.

Giovannetti, M. and B-Mosse (1980). An evaluation of methods for measuring vesicular arbuscular mycorrhizal infection in roots. New. Phytol., 84:489-500.

Gryndler, M., J. Lestina, V. Moravec, Z. Prikyl and J. Lipavsky (1990). Colonization of maize roots by VAM Fungi under conditions of long-term fertilization of varying intensity. Agric. Ecosyst. Environ., 29: 183-186.

Hause B., W. Marier, O. Miersch, R. Kramell and D. Strack (2002). Induction Jasmonate biosynthesis in arbuscular mycorrhizal barley roots. Plant Physiology, 130: 12311220 .

Hol, G.W.H and R. Cook (2005). An overview arbuscular mycorrhizal fungi nematode interactions. Basic and Appl. Ecol., 6: 489-503.

Kloepper, j.W., Ryu, C.M. and Zhang, S. (2004). Induced systemic resistance and promotion of plant growth by Bacillus spp. Phytopathology, 94: 1259-1266.

Mesbah, H.A., E.H. Tayeb, A.Z. EL-Naggar and M.S. ELShahaat (2007). The relative efficiency of some pesticides and fertilizers on cotton crop. Interaction effects of fertilizer type and some insecticides on bollworms infestation and cotton quality. J. Adv. Agric. Res. 12 (1): 115-126.

Mesbah, H.A., A.K. Mourd, Hanyiat M. EL-Nimr, M.A. Massoud A.A. Abd EL-Aziz (2002a). The role of some agricultural practices and fertilizer type on both the incidence of stem borers infestation and corn yield in Egypt. Department of Plant Protection, Alexandria Univiersty, Alexandria, Egypt, 6713: 575-589.

Mesbah, H.A., A.K. Mourd, Hanyiat M. EL-Nimr, Magda B. EL-Kady and Nagah S. Haroun (2002b). Effect of sequential applications of foliar nutrients, bio-fertilizers and sowing dates on the incidence of corn stem borers in Egypt. Department of Plant Protection, Alexandria University, Alexandria, Egypt, 6713: 489-497.

Mesbah, H.A., E.H. Tayeb, M.M. EL-Bassiobny and A.Z. ELNaggar (2005). The efficacy of some plant nutrients and alternative chemicals against the spiny bollworms Earias insulana (Lepidoptera: Noctuidae), at Alexandria Governorate. J. Adv. Agric. Res. 10 (4): 1015-1036.

Pozo, M.J., A. verhage, J. Cacia- Andrade, J. M. Garcia and C. Azocon-Aguilar (2008). Priming plant defense against pathogens by arbscular mycorrhizal fungi. Plant .1-12.

Ride, J.P. (1975). lignification in wounded leaves in response to fungi and its possible role in resistance. Physiological Plant Pathol., 5: 125-134. 


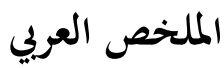

\section{تقدير كفاءة فطر الميكوريزا الداخلية والبكتيريا المصاحبة للجذور على الإصابة بثاقبات الذرة}

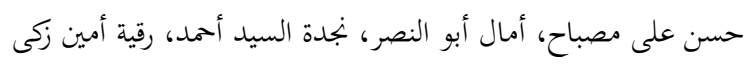

$$
\begin{aligned}
& \text { بالفطريات الداخلية (G3) +(Gacillus mycoides } \\
& \text { بالكنترول فن وجود كلا نوعى التسميد العضوى والمعدنى. } \\
& \text { تم إجراء التجارب الحقلية في المزرعة التجريية- كلية الزراعة (سابا }
\end{aligned}
$$

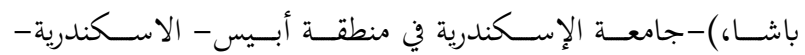

$$
\begin{aligned}
& \text { أمكن التأكد من التتائج من خلال العلاقة القوية بين قيم محتوى }
\end{aligned}
$$

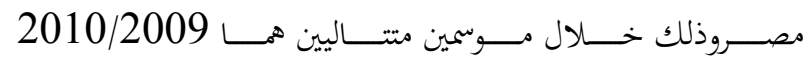

$$
\begin{aligned}
& \text { اللجنين في سيقان نباتات الذرة فن وجود مستويات الإصابة بثاقبات } \\
& \text { و 2011/2010وذلك تلقيبيم تأثير فطراميكوريزا الداخلية (AMF) }
\end{aligned}
$$

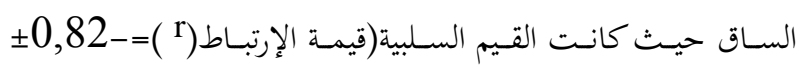

$$
\begin{aligned}
& \text { 0,12 \& -0,80 × 0,12) فن وجود تحت كلا نوعى التسميد } \\
& \text { في وجود نوعين من الأسمدة العضوية والمعدنية على الإصابة بثاقبات }
\end{aligned}
$$

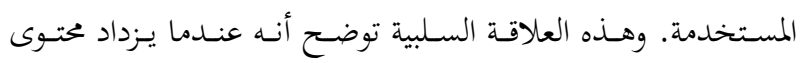

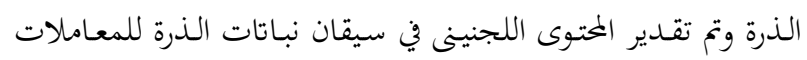

$$
\begin{aligned}
& \text { اللجنين في سيقان نباتات الذرة، تنخفض الإصابة بثاقبات الساق. } \\
& \text { أوضحت النتائج التي تم الحصول عليها، أن أقل متوسط تعداد من }
\end{aligned}
$$

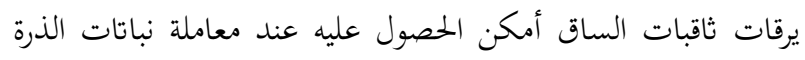

